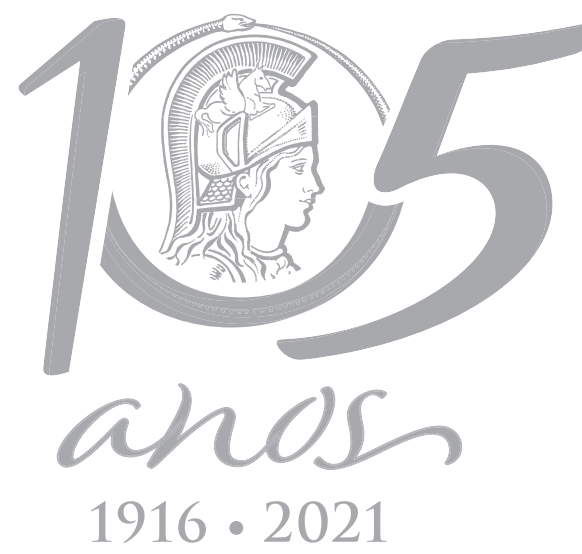

\title{
PALEONTOLOGY
}

\section{The history, importance and anatomy of the specimen that validated the giant Purussaurus brasiliensis Barbosa- Rodrigues 1892 (Crocodylia: Caimaninae)}

\author{
LUCY G. DE SOUZA, KAMILA L.N. BANDEIRA, RODRIGO V. PÊGAS, ARTHUR S. \\ BRUM, RODRIGO MACHADO, EDSON GUILHERME, THIAGO S. LOBODA \& \\ JONAS P. DE SOUZA-FILHO
}

\begin{abstract}
The Solimões Formation is a southwest geological unit of the Brazilian Amazon, being well-known for the Cenozoic giant eusuchian fossils. Among the eight species of Crocodylia described for this formation, the alligatoroid Purussaurus brasiliensis is the best known worldwide due to its enormous size. The holotype was described in 1892 by Barbosa-Rodrigues, composed by a right hemimandible. Later, two other species were assigned to the genus, but the loss of the type specimen brought a series of doubts and discussions about genus and species validity. Here, we provide a historical reconstruction of the genus Purussaurus, especially with a new description of the specimen DGM 527-R, which was first described by L. I. Price. We also provide a review of Purussaurus brasiliensis as a valid species, highlighting the importance of the paleontologist Diogenes de Almeida Campos to the preservation, study availability and divulgation of the specimen. From the six mandibular features discussed, at least two are putative synapomorphies for the genus: the false ziphodont teeth and the thinning of the medial surface of the mandible posterior to the fourteen alveoli, while the lateral surface become laterally expanded from ninth alveoli to behind. The review of the other species of the genus was aggravated due to little sampling of photos and low quality of those contributions. Finally, the curatorial efforts initiated by Price and kept for decades by Campos turned possible the revision of DGM 527-R, an important specimen for understanding the paleobiology and evolution of the genus, and, consequently $P$. brasiliensis. Such importance was recognized here scientifically and by Campos when considered this specimen as the center-piece of the exhibition in honor of the centenary anniversary of Price.
\end{abstract}

Key words: Alligatoroidea, Amazon, Brevirostris, Diogenes de Almeida Campos, Llewellyn Ivor Price, Solimões Formation.

\section{INTRODUCTION}

The specimens of Purussaurus are known from the Miocene of South America, having been recovered from four different countries: Brazil (Solimões Formation, P. brasiliensis; BarbosaRodrigues 1892, Price1967, Bocquentin-Villanueva et al. 1989, Souza et al. 2016), Colombia (Honda
Group and Castilletes Formation, P. neivensis; Mook 1941a, Langston 1965), Peru (Pebas Formation, P. neivensis [?]; Salas-Gismondi et al. 2015), and Venezuela (Urumaco Formation, P. mirandai; Aguilera et al. 2006, Scheyer et al. 2013, Scheyer \& Delfino 2016). The genus Purussaurus was described in 1892 by BarbosaRodrigues when the species $P$. brasiliensis 
Barbosa-Rodrigues, 1892 was erected, based on a right hemimandible that preserves the first nine alveoli. After its description, two other species were assigned to the genus: $P$. neivensis (Mook 1941a) and P. mirandai Aguilera, Riff \& Bocquentin-Villanueva, 2006 (Aguilera et al. 2006). For a complete history of the genus as well as their relationship with Dinosuchus terror (Gervais 1876) and Brachygnatosuchus brasiliensis (Mook 1921a) see Aguilera et al. (2006).

Unfortunately, some years after the description of Purussaurus brasiliensis, the Museu Botânico do Amazonas (Manaus, Amazonas, Brazil) was closed in 1890, and the type specimen was never recovered, currently being considered lost (see Price, 1967 for a detailed history of the whereabouts of the holotype). Due to the fragmentary status of the holotype and the fact that it was missing, the validity of $P$. brasiliensis was debated (Patterson 1936, 1943). However, both the genus and the type species of $P$. brasiliensis are considered as valid and their diagnoses were properly established (Price 1967, Bocquentin-Villanueva et al. 1989, Aguilera et al. 2006). Despite recent attempts to improve our understanding on Purussaurus species (e.g., Blanco et al. 2015, Aureliano et al. 2015, Scheyer \& Delfino, 2016, Scheyer et al. 2019), most of its anatomy is still unclear. A significant number of fossils are attributed to the three species of Purussaurus, mainly based on their size and overall shape (e.g., Price 1967, Bocquentin-Villanueva et al. 1989, Scheyer et al. 2013, 2019, Salas-Gismond et al. 2015, Souza et al. 2016, Scheyer \& Delfino 2016, Solórzano et al. 2018). However, few works adequately describe and compare their anatomy (e.g., Aguilera et al. 2006, Souza-Filho et al. 2019). Also, a new species, Acresuchus pachytemporalis SouzaFilho et al., 2019, from Solimões Formation was recently described and inferred to be the sister species of Purussaurus. Nevertheless, further studies should better address the anatomy and evolution of this clade (Souza-Filho et al. 2019). Some recent and preliminary efforts compared the type specimens of Purussaurus and probably related species, providing some hypotheses regarding the validity of a few species (G. M. Cidade \& A. Hsiou unpublished data).

The present contribution presents a historical reconstruction of the importance of L.I. Price's work in the corroboration of Purussaurus brasiliensis as a valid species and exalts the importance of Diogenes de Almeida Campos in the preservation, study availability, and divulgation of the specimen that will be here redescribed.

Herein we redescribe the specimen collected and described by Price (1967) and figure it for the first time in the literature. We also include comments on the mandibular characters of Purussaurus, aiming to provide a solid anatomical base for future studies with those species.

ANATOMICAL ABBREVIATIONS: $\mathbf{1}^{\text {st }}$, first dentary alveolus; $\mathbf{4}^{\text {th }}$, fourth dentary alveolus; $13^{\text {th }}$, thirteenth dentary alveolus; an, angular; $\mathbf{d}$, dentary; mg, Meckelian groove; san, surangular; sp, splenial.

INSTITUTIONAL ABBREVIATIONS: AMNH, American Museum of Natural History, New York, USA; AMU-CURS, Alcaldía del Municipio Urumaco, Venezuela; ANSP, Academy of Natural Sciences of Drexel University, Philadelphia, USA; CIAAP, Centro de Investigaciones Antropológicas, Arqueológicas y Paleontológicas, Universidad Nacional Experimental Francisco de Miranda, Coro, Venezuela; CM, Carnegie Museum of Natural History, Pittsburgh, USA; DGM, Divisão de Geologia e Paleontologia do Departamento Nacional de Produção Mineral, Rio de Janeiro, Brazil; IVIC, Colección de Paleontología del Instituto Venezolano de Investigaciones Científicas, 
Caracas, Venezuela; Kr-C-\#, Krabi crocodylian, Sirindhorn Museum, Kalasin Province, Thailand; MCNC, Museo de Ciencias Naturales de Caracas, Venezuela; MCN-USB, Museo de Ciencias Naturales, Universidad Simón Bolivar, Caracas, Venezuela; MCT, Museu de Ciências da Terra, Rio de Janeiro, Brazil; MPEF, Museo de Paleontología Egidio Feruglio, Trelew, Argentina; MUSM, Museum of San Marcos University, Lima, Peru; MZUSP, Museu de Zoologia da Universidade de São Paulo, São Paulo, Brazil; NJSM, New Jersey State Museum, Trenton, USA; PVL, Colección Paleontología Vertebrados, Instituto Miguel Lillo, Tucumán, Argentina; TMM, Texas Memorial Museum, Austin, USA; SMM, Science Museum of Minnesota, St. Paul, USA; UCMP, University of California Museum of Paleontology, California, USA; UF, University of Florida, Florida Museum of Natural History, Gainsville, USA; UFAC, Universidade Federal do Acre, Rio Branco, Brazil; UM, University of Michigan Museum of Paleontology, Ann Arbor, USA; UNEFM-CIAAP, Universidad Nacional Experimental Francisco de Miranda, Coro, Venezuela; USNM, United States National Museum, Smithsonian Institution, Washington DC, USA.

\section{FROM THE FIELDWORK TO THE CENTRAL PIECE OF PRICE EXPOSITION}

After the Barbosa-Rodrigues (1892) holotype of Purussaurus brasiliensis (Figure 1a-c), the second specimen formally attributed to the species, DGM 527-R (Figure 1d), was collected in 1962 in a Project named "Colaboração em Pesquisas Paleontológicas" from Petróleo Brasileiro S.A. (PETROBRAS) with the Divisão de Geologia e Mineralogia (DGM) from Departamento Nacional de Produção Mineral (former DNPM, nowadays the Agência Nacional de Mineração - ANM; Price 1967). This expedition visited and recognized new outcrops from the hydrographic basin of the Juruá-Mirim River, affluent from the Juruá River (Price 1967). The outcrop, named Petrópolis, was located in a 'Terra Firme' region in the left side of the upstream Juruá River, State of Acre, between Porto Walter and the debouchment of Igarapé Ouro Preto (Price 1967).

The transport of the material was made via airplane to Rio de Janeiro (Campos, personal communication). The fossil comprises a mandible of $1,75 \mathrm{~m}$ maximum length. However, during transportation and packaging into the collection, the material broke into at least three portions: 1) the anterior portion; 2) the posterior portion of the left hemimandible; 3 ) the posterior of the right hemimandible. The anterior portion (1) includes the fused mandibular symphysis of the hemimandibles, with 14 alveoli in the left and right side, and half of the $15^{\text {th }}$ alveolus in the former. The left hemimandible (2) includes the remaining alveoli (total of 21) and the mandibular fenestra extension until the retroarticular process. The right hemimandible (3) includes

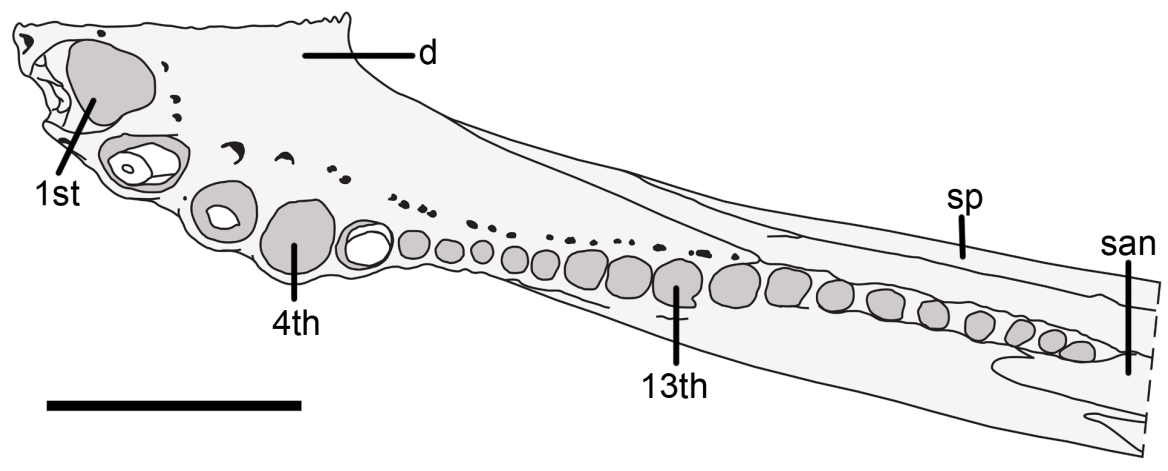

Figure 1: Purussaurus brasiliensis specimens. The holotype, modified reproduction of original plate drawings of Barbosa-Rodrigues (1892), in a) dorsal (occlusal) view; b) ventral view; and, c) medial view; and, d) schematic drawing of DGM 527-R based on original work of Price (1967). Scale bar: $20 \mathrm{~cm}$. 
the remaining alveoli and the anterior parts of the mandibular fenestra. From those, only the (1) and (3) portions were recovered until the finalization of the present work.

The species assumes a dubious status due to the fragmentary state and loss of the holotype (e.g., Patterson 1936). The specimen DGM 527-R described by Price (1967) and its reassessment were the keystones for a clear understanding of Purussaurus brasiliensis.

A new exposition in the Museu de Ciências da Terra was inaugurated in 2005, in honor of the memory of L. I. Price's centenary (25 years after his death in 1980), named "Llewellyn Ivor Price + 100, um Paleontólogo". L. I. Price was the advisor of Diogenes de Almeida Campos and enabled him to study paleontology and develop fieldworks, including activities in the state of Acre. Diogenes was responsible for the organization of this exposition and decided to put DGM 527$\mathrm{R}$ in the central portion of the exhibition due its grandiosity, beauty and importance, and to honor the efforts to collect and bring this enormous and historical specimen to the MCT collections (Figure 2).

\section{GEOLOGICAL BACKGROUND}

\section{Solimões Formation}

The Solimões Formation crops out in Amazonas and Acre states (Brazil), yielding a high diversity of fossils (Riff et al. 2010), including plants, invertebrate and vertebrate remains (Latrubesse et al. 2010). This formation is characterized by several facies of conglomerates, sandstones and mudstones with fining upward vertical profiles, showing high lateral heterogeneities (Caputo et al. 1971, Brazil 1976). Following Souza et al. (2016), we assume the Eocene-Pliocene age and thickness of 2,200 $\mathrm{m}$ associated with the Andean Orogeny (Cunha 2007) and fluvial paleoenvironment (Caputo et al. 1971), with the outcropped rocks assigned to the Upper Miocene (Latrubesse et al. 2010, Bissaro-Júnior et al. 2018).

\section{Studied Locality}

The outcrop where DGM 527- $\mathrm{R}$ was collected is named as Petrópolis (Locality 43 in the original contribution, but Locality 18 in RADAMBRASIL vol. 13; Price et al. 1977), a 'Terra Firme' region in the left side of the upstream Juruá River, State of Acre, between Porto Walter and the debouching of Igarapé Ouro Preto (Price 1967).

As the Petrópolis locality was in a riverbank, this area described by Price (1967) was lost due to the natural erosion that occurs in this kind of outcrop. Therefore, we provide the main geological and stratigraphic information of that site based on Price (1967).

Petrópolis locality was a terrace outcrop located four meters above the water level during the 1962 dry season of Juruá River. Two layers are described: the first is thin, friable clays, predominantly reddish-pink colors arranged in bands, indicating poor lodging; the second one, which contains the fossil remains, is characterized by clayey sandstone, fine, limestone, light gray (Price 1967). The mandible was found with only the symphyseal portion nested within the rock matrix. Also, other fossil remains were recovered from the same level such as smaller crocodylians (Crocodylia), deers (Cervidae), gastropods and bivalves, which attribute a Pliocene-Pleistocene age for this level (Price 1967). The recovered fossils lack signals of transportation and were found in situ (Price 1967). Based on the outcropping region and the recovered fossils of this rock, they indicate a deposition during the Upper MiocenePliocene of the Solimões Formation. However, it is important to note that the surrounding outcrops present different ages such as Eocene (Bond et al. 2015) and Pleistocene (Latrubesse \& Rancy 2000). 


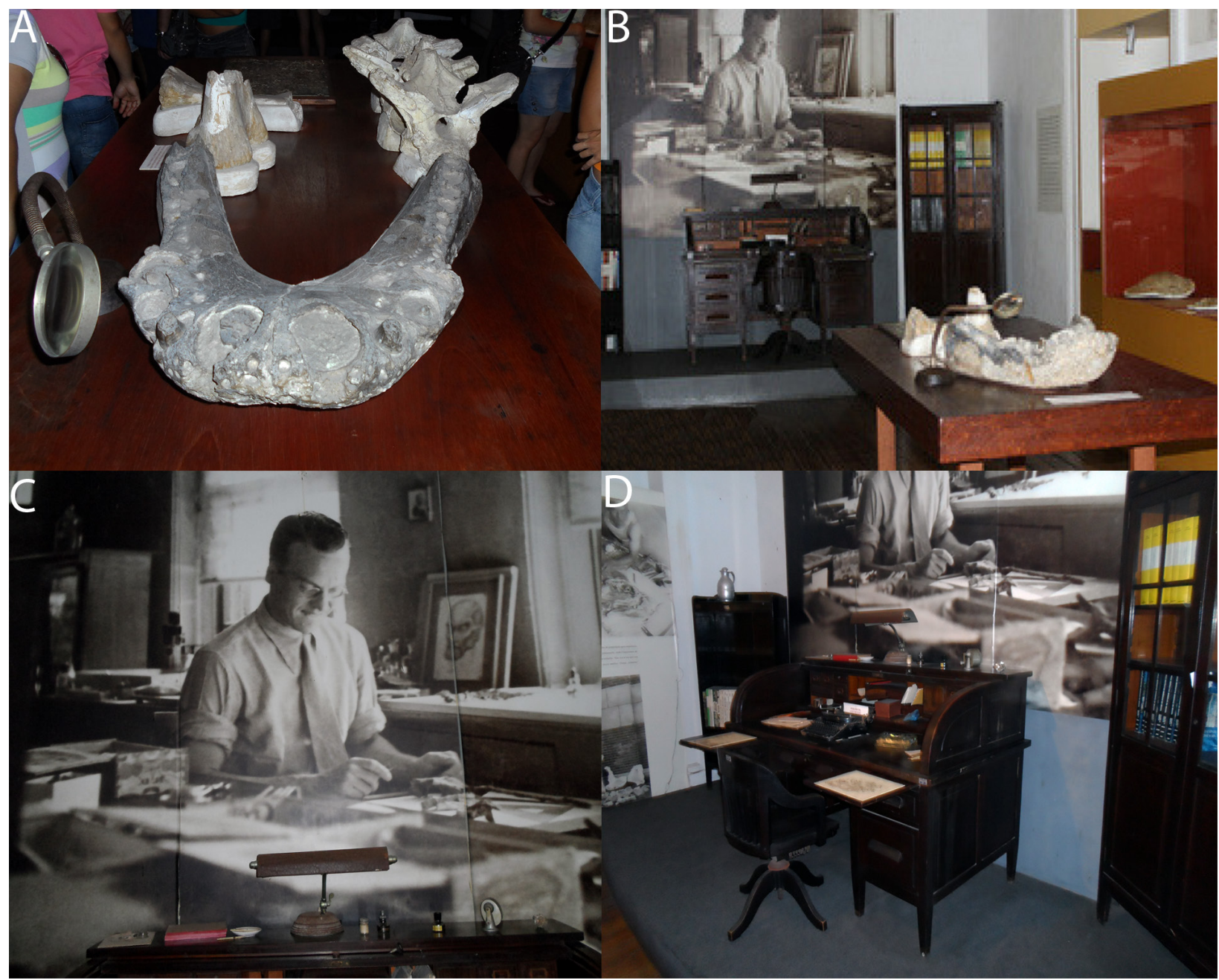

Figure 2: Photographs of the exhibition "Llewellyn Ivor Price + 100, um Paleontólogo", curated by Diogenes de Almeida Campos. a) the anterior portion of DGM 527-R was exposed on the central table; $b$ ) wide view of the room with the central table including DGM 527-R; c) picture of L. I. Price used as the background of the exhibition; and, d) reconstitution of the original L. I. Price working table.

\section{MATERIAL AND METHODS}

\section{Studied specimens and species}

The specimen in focus here is the mandible of Purussaurus brasiliensis (DGM 527-R). As already mentioned, the specimen was almost complete, but the posterior portions of the mandible is lost. The specimens of $P$. brasiliensis UFAC 1118 and the holotype, which was based on descriptions and original drawings presented by Barbosa-Rodrigues (1892), are included in the comparisons (Figure 1a-c). The holotypes and referred specimens of $P$. neivensis and P. mirandai are also compared as well as mandibular remains referred to Purussaurus sp. (Table I).

As Purussaurus is well known to belong to the Caimaninae, the comparisons were predominantly based on species within this clade and other closely related forms within Alligatoroidea. Therefore, all extant Caimaninae species were included in this study (Table II; see Souza 2018 for developmental categories of the specimens). Regarding the fossil specimens, all 
Table I. The studied mandibular elements of Purussaurus mirandai, P. neivensis and Purussaurus sp. specimens. Legend: *, type specimen.

\begin{tabular}{|c|c|c|}
\hline TAXA & REGISTER NUMBER & REFERENCE \\
\hline \multirow{2}{*}{ Purussaurus mirandai } & UNEFM-CIAAP-1369* & $\begin{array}{l}\text { Bocquentin-Villanueva et al. 1989, Aguilera } \\
\text { et al. 2006, Scheyer \& Delfino } 2016\end{array}$ \\
\hline & UNEFM-CIAAP 1445 & Aguilera et al. 2006, Scheyer \& Delfino 2016 \\
\hline \multirow{4}{*}{ Purussaurus cf. P. mirandai } & AMU-CURS- 057 & Scheyer \& Delfino 2016 \\
\hline & AMU-CURS-541 & Scheyer \& Delfino 2016 \\
\hline & AMU-CURS-685 & Scheyer \& Delfino 2016 \\
\hline & MCNUSB no number & Scheyer \& Delfino 2016 \\
\hline \multirow{4}{*}{ Purussaurus neivensis } & USNM 10889* & Mook 1941 \\
\hline & MUSM 1392 & Salas-Gismond et al. 2015 \\
\hline & UCMP 39657 & Langston 1965 \\
\hline & UCMP 40279 & Langston 1965 \\
\hline \multirow{9}{*}{ Purussaurus sp. } & IVIC-P-668 & Solórzano et al. 2018 \\
\hline & MCNC-URU-115-72V & Scheyer \& Delfino 2016 \\
\hline & MCNC-URU-158-72V & Scheyer \& Delfino 2016 \\
\hline & MCNC-76-72V & Scheyer \& Delfino 2016 \\
\hline & MCNC-URU-90-72V & Scheyer \& Delfino 2016 \\
\hline & MCNC-URU-111-72V & Scheyer \& Delfino 2016 \\
\hline & MCNC-URU-111-72V & Scheyer \& Delfino 2016 \\
\hline & AMU-CURS-394 & Scheyer \& Delfino 2016 \\
\hline & AMU-CURS-671 & Scheyer \& Delfino 2016 \\
\hline
\end{tabular}

those with mandibular remains were included for comparisons (Table III).

\section{Osteological nomenclature}

The osteological nomenclature of mandibular bones is based on Mook (1921b), Romer (1956) and Iordansky (1973).

\section{Specimen information acquisition}

The historical information about the analyzed specimen was based on literature (e.g., Price 1967, Price et al. 1977), the register book of the collection, and personal communication provided by Diogenes de Almeida Campos.

\section{RESULTS}

\section{Systematic}

CROCODYLIA Gmelin, 1789 (sensu Benton and Clark, 1988) ALLIGATOROIDEA Gray, 1844 (sensu Brochu, 2003, following Norell et al., 1994)

CAIMANINAE Brochu, 1999 (following Norell 1988) 


\section{Purussaurus Barbosa-Rodrigues, 1892}

Type-species: Purussaurus brasiliensis

Diagnosis: Few works have discussed and established diagnoses for Purussaurus based on phylogenetic inference. The first, performed by Aguilera et al. (2006), included only P. mirandai and P. neivensis. The diagnosis comprises: "the retroarticular process projecting posteriorly and not posterodorsally (reversion among the Crocodylia); the surangular is pinched off anterior to the tip of the retroarticular process (a reversion among the Caimaninae); the external mandibular fenestra is large, with the foramen intermandibularis caudalis visible laterally; the supraoccipital is large, but does not exclude the parietal from the posterior edge of the skull table (an unambiguous synapomorphy, also found in the Paleosuchus clade); the presence of a fossa around the supratemporal fenestra (a reversion among the Caimaninae)."

A complete phylogenetic inference of the clade, including all taxa and its sister species, was made by Souza-Filho et al. (2019), which recognized the following features as diagnostic: “(1) external naris longer than wide (character 83-2), which is a unique synapomorphy; (2) orbits equal or subequal in size to the infratemporal fenestrae (character 181-0), a character shared convergently with Acynodon iberoccitanus Buscalioni, Ortega, and Vasse, 1997, Kambara implexidens Salisbury and Willis, 1996, Brachychampsa montana Gilmore, 1911, Diplocynodon darwini (Ludwig, 1877), D. hantoniensis (Wood, 1846), and D. ratelii Pomel, 1847; and (3) posterior margin of the skull deeply concave (character 185-1), a character shared with Thecachampsa americana (Sellards, 1915)."

\section{Purussaurus brasiliensis Barbosa-Rodrigues, 1892}

Holotype: specimen described and figured by Barbosa-Rodrigues (1892), which is lost.
Table II. Studied extant Caimaninae species and specimens.

\begin{tabular}{|c|c|}
\hline SPECIES & SPECIMEN \\
\hline \multirow{8}{*}{ Caiman crocodilus } & AMNH R 73048 \\
\hline & AMNH R 137179 \\
\hline & DGM 155-RR \\
\hline & DGM 300-RR \\
\hline & MZUSP-C 2014 \\
\hline & MZUSP-C 2063 \\
\hline & MZUSP-C 2113 \\
\hline & USNM 313860 \\
\hline \multirow{6}{*}{ Caiman latirostris } & AMNH R 143183 \\
\hline & DGM 156-RR \\
\hline & MNRJ 1445 \\
\hline & MZUSP-C 2137 \\
\hline & UF 99046 \\
\hline & UF 99223 \\
\hline \multirow{8}{*}{ Caiman yacare } & AMNH R 97305 \\
\hline & AMNH R 97334 \\
\hline & AMNH R 120028 \\
\hline & MNRJ 25460 \\
\hline & MZUSP-C 2138 \\
\hline & MZUSP-C 2140 \\
\hline & UF 121249 \\
\hline & USNM 297784 \\
\hline \multirow{5}{*}{ Melanosuchus niger } & AMNH R 58130 \\
\hline & AMNH R 101419 \\
\hline & DGM XXX \\
\hline & UFAC 1 \\
\hline & UFAC 2 \\
\hline \multirow{6}{*}{ Paleosuchus palpebrosus } & AMNH R 97327 \\
\hline & AMNH R 97328 \\
\hline & AMNH R 147051 \\
\hline & MZUSP-C 2224 \\
\hline & UF 62509 \\
\hline & UF 75023 \\
\hline \multirow{5}{*}{ Paleosuchus trigonatus } & AMNH R 66391 \\
\hline & MZUSP-C 2214 \\
\hline & UF 61981 \\
\hline & USNM 213705 \\
\hline & USNM 562714 \\
\hline
\end{tabular}


Table III. Studied fossil species and specimens. Legend: *, type specimen; bold, specimen personally studied; italic, donated photographs of the specimen.

\begin{tabular}{|c|c|c|}
\hline SPECIES & SPECIMEN & REFERENCE \\
\hline Acresuchus pachytemporalis & UFAC-2507* & Souza-Filho et al. 2019 \\
\hline Bottosaurus harlani & ANSP 9227*; NJSM 11265 & Cossette \& Brochu 2018 \\
\hline Caiman brevirostris & UFAC 196*; UFAC 5388 & $\begin{array}{l}\text { Souza-Filho 1987, Fortier et al. 2014, } \\
\text { Scheyer \& Delfino } 2016\end{array}$ \\
\hline Ceratosuchus burdoshi & UM 68238 & Bartels 1984 \\
\hline Culebrasuchus mesoamericanus & UF $244434^{*}$ & Hastings et al. 2013 \\
\hline Eocaiman cavernensis & AMNH $3158^{*}$ & $\begin{array}{c}\text { Simpson 1933, Pinheiro et al. 2013, Bona } \\
\text { \& Barrios } 2015\end{array}$ \\
\hline Eocaiman paleocenicus & MPEF-PV 1933* & $\begin{array}{c}\text { Bona 2007, Pinheiro et al. 2013, Bona \& } \\
\text { Barrios } 2015\end{array}$ \\
\hline Eocaiman itaboraiensis & $\begin{array}{l}\text { MCT 1791-R*; MCT 1792-R; } \\
\text { MCT 1793-R }\end{array}$ & Pinheiro et al. 2013 \\
\hline Gnatusuchus pebasensis & $\begin{array}{c}\text { MUSM 662; MUSM 1979; } \\
\text { MUSM } \\
2040\end{array}$ & Salas-Gismondi et al. 2015 \\
\hline Globidentosuchus brachyrostris & AMU-CURS-222* & $\begin{array}{c}\text { Scheyer et al. 2013, Scheyer \& Delfino } \\
2016\end{array}$ \\
\hline Krabisuchus siamogallicus & $\mathrm{Kr}-\mathrm{C}-012^{*}$ & Martin \& Lauprasert 2010 \\
\hline Kuttanacaiman iquitosensis & MUSM 1490*; MUSM 1942 & Salas-Gismondi et al. 2015 \\
\hline Mourasuchus amazonensis & $D G M 526-R^{*}$ & Cidade et al. 2019a \\
\hline Mourasuchus arendsi & CIAAP-1297* & Cidade et al. 2018 \\
\hline Mourasuchus atopus & UCMP 38012* & Langston 1965 \\
\hline Mourasuchus pattersoni & MCNC-PAL-110-72V* & Cidade et al. 2017 \\
\hline Navajosuchus mooki & AMNH $6780^{*}$ & Simpson 1930, Lucas \& Estep 2000 \\
\hline Necrosuchus ionensis & AMNH 3219* & $\begin{array}{l}\text { Simpson 1937, Brochu 2011, Bona \& } \\
\text { Barrios 2015, Cidade et al. 2019b }\end{array}$ \\
\hline Notocaiman stromeri & PVL 752* & Bona \& Barrios 2015 \\
\hline Procaimanoidea utahensis & USNM 15996*; USNM 15997* & Gilmore 1946 \\
\hline Procaimanoidea kayi & CM $9600^{*}$ & Mook 1941b \\
\hline Tsoabichi greenriverensis & TMM 42509-1* & Brochu 2010 \\
\hline Wannaganosuchus brachymanus & SMM P76.28.247* & Erickson 1982 \\
\hline
\end{tabular}


Referred specimens: DGM 527-R and UFAC 1118.

Diagnosis: the diagnoses proposed in the literature for Purussaurus brasiliensis are outdated and should be updated. Here, some mandibular characters are presented as autapomorphic for $P$. brasiliensis, at least within the genus, based on Cidade et al. (2019c) and G. M. Cidade \& A. Hsiou (unpublished data): the first four dentary alveoli are proportionally larger than in P. mirandai and the $13^{\text {th }}$ alveolus is larger than the posterior and the seven anterior, to the fourth (observed in Necrosuchus and Paleosuchus).

\section{DESCRIPTION}

Unfortunately, Price (1967) did not entirely illustrate DGM 527-R (Figure 1d) and, as portions
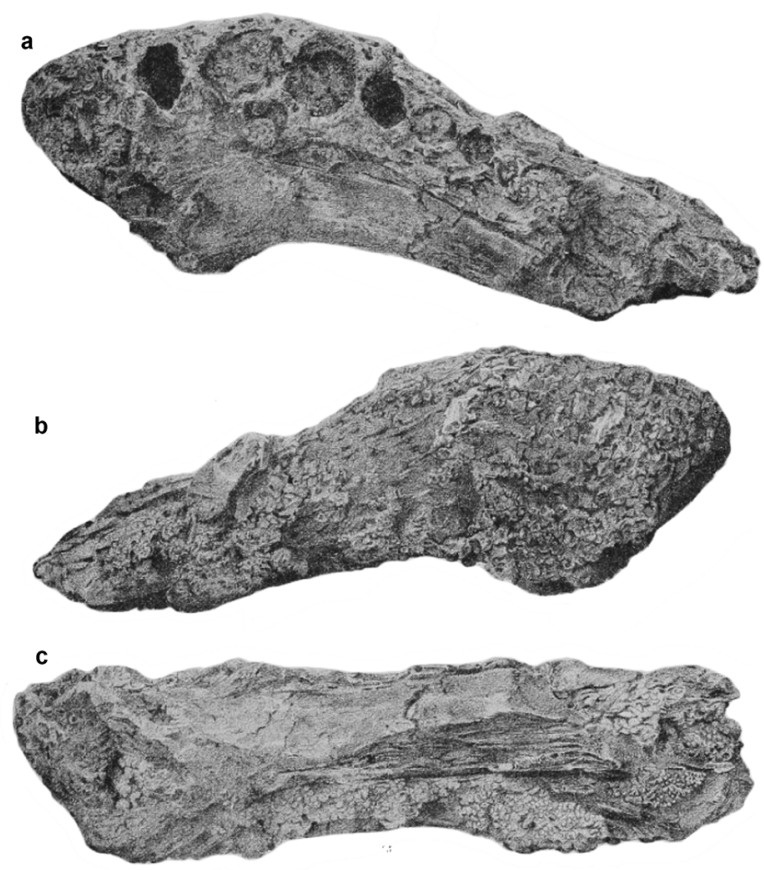

Figure 3. The mandible specimen of Purussaurus brasiliensis (DGM 527-R) and their respective schematic drawing. a) dorsal (occlusal) view; b) right lateral view; and, c) posterior view of the mandibular symphysis. Scale bar: $20 \mathrm{~cm}$. of the specimen are missing, we based its general description on the textual information provided by him. The specimen DGM 527-R consists of an entire left hemimandible articulated at the symphysis with the right hemimandible, which preserves only its anterior half. Based on the recovered portions of DGM 527-R (Figure 3, 4) the following bones are preserved: dentary, splenial, surangular and angular. The dentition is not complete, including only a few preserved teeth, but the dental formula can be reconstructed by the number of alveoli on both sides of the mandible. From the left hemimandible, the following bones are damaged: the central portion of the surangular, over the mandibular fenestra; the anterior facet for the Meckel cartilage; the medial border of glenoid surface and medial border of retroarticular process.

The dentaries of both hemimandibles join medially, creating the mandibular symphysis that extends along five alveoli, reaching the anterior half of the fifth (Figure 1d,3a). The dorsal surface of the symphysis is dorsoventrally inclined. The anterior half of this surface, with the alveolar region, is taller than the posterior half, which corresponds to the posterior margin of symphysis (Figure 3b, c, 4a, d). In the posterior surface of the mandibular symphysis, in the most ventral portion, there is the Meckelian groove, visible as a large lateromedially expanded and dorsoventrally compressed foramen (Figure 3c). In dorsal view, the dentary contacts the splenial, and medially by the surangular (Figure $1 d, 3 a, b)$. At the medial surface, the dentary contacts posteriorly and it is covered by the splenial (Figure 3a, 4b). In the lateral surface, the dentary contacts the angular ventrally at the anterior margin of the mandibular fenestrae at the mid-portion. The surangular contacts it dorsally (Figure 3a, b). There are 21 preserved alveoli in DGM 527-R (only 14 on the left side in the preserved region), all of them are dorsally 

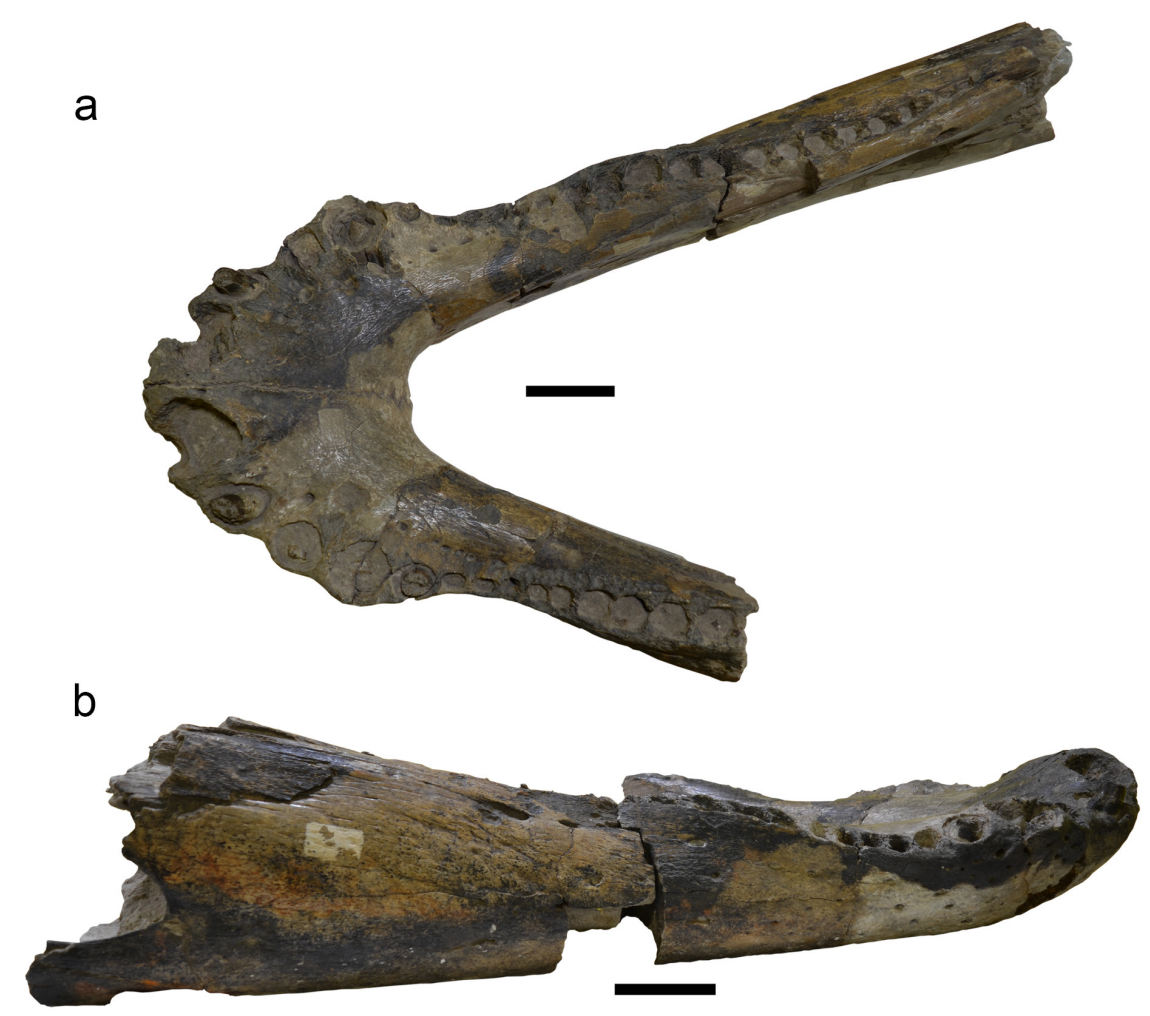

Figure 4. The mandible specimen of Purussaurus brasiliensis (DGM 527-R). a) ; b) medial view of right hemimandible; c) anterior view; d) anterodorsal view. Scale bar: $20 \mathrm{~cm}$.

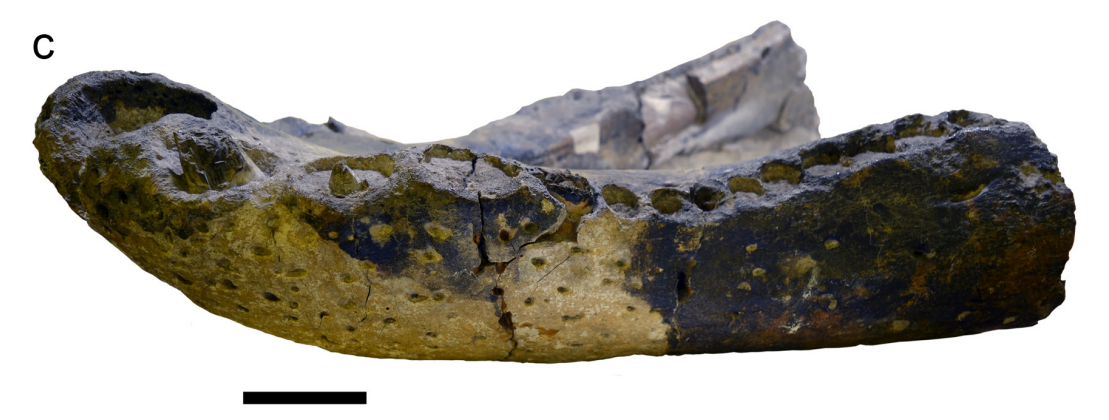

directed (Figure 1d, 3a, 4d). The largest alveoli are the first and fourth with similar sizes, followed by the second and third (Figure 1d, 3a, 4d). The fifth and thirteenth alveoli have similar sizes, but the thirteen is slightly larger than the fifth. Despite their size, they are smaller than the second/ third. The sixth alveolus is the smallest with the seventh until twelfth growing continuously and progressively (Figure 3a). From the fourteenth to the twenty-second, the alveoli reduce in size continuously (Figure 3a). In lateral view, the region of the first alveoli is the tallest, followed by a concavity, along the second and third alveoli, being limited by the fourth alveolus that has almost the same height as the first (Figure $3 b, c, 4 a)$. In the region of the fifth to the eleventh alveoli there is another concavity in lateral view, while from the twelfth alveolus to the posterior region of the dorsal margin of mandible, they are inclined dorsally and become continuously tall (Figure 3a, b). In dorsal view, the second alveolus is posterolaterally displaced to the first. The 

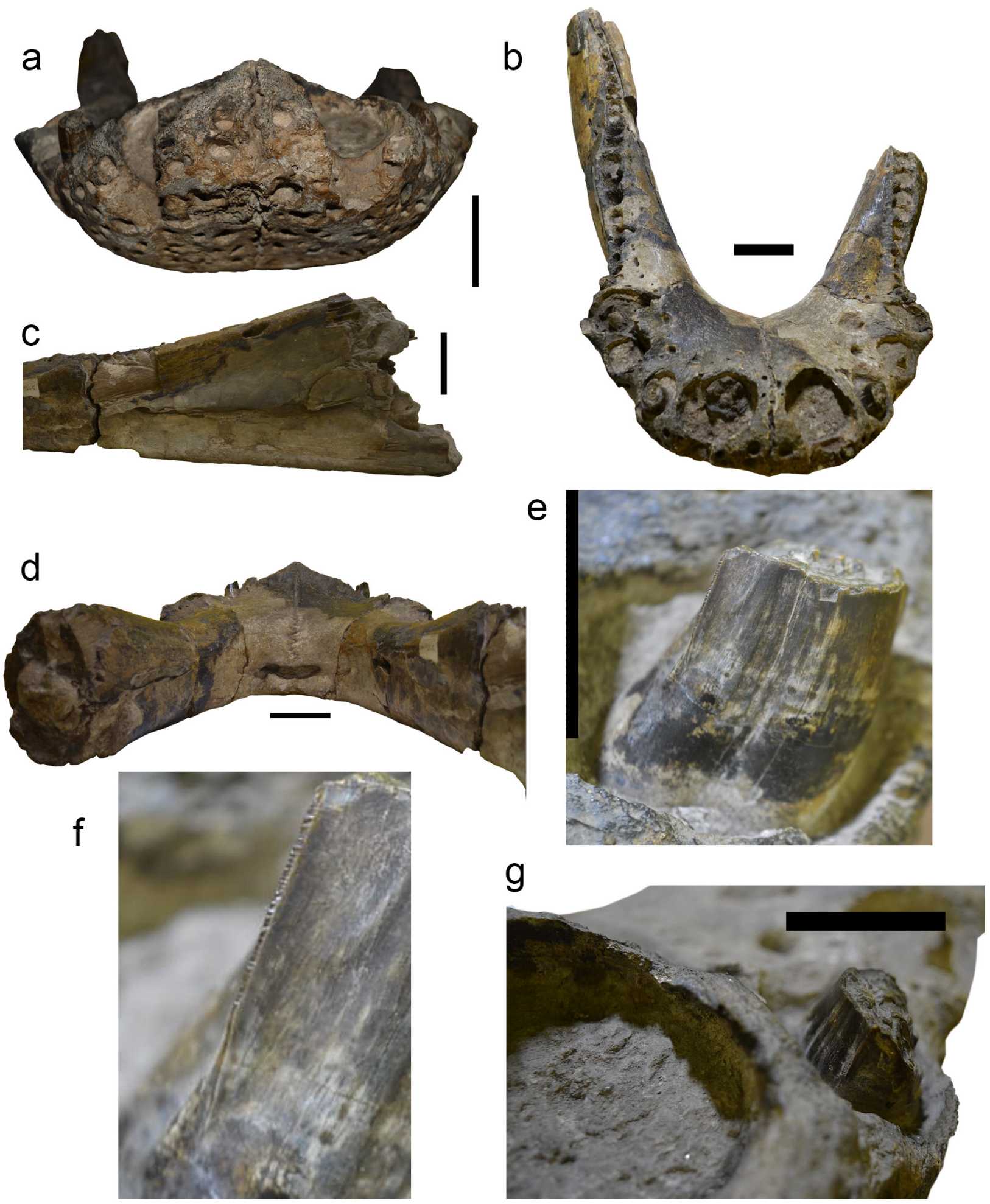

Figure 5. Detail of the mandible specimen of Purussaurus brasiliensis (DGM 527-R). a) anterior view of the in situ tooth of the left side second alveolus; b) labial view of the in situ tooth of the right side second alveolus; and, $c$ ) Zoom in the carinae of the tooth figured in b. Scale bar a and b: $5 \mathrm{~cm} ; \mathrm{c:}: 1 \mathrm{~cm}$. 
mid-section of the second alveolus is aligned with the posterior margin of the first. The third alveolus is located posterolaterally in relation to the lateral margin of the second alveolus, while the fourth and the fifth follow anteroposteriorly the third. Such conformation shows a convex lateral margin of the anterior mandible (Figure $3 a, 4 c, d)$. A consequence of the different size of the alveoli, the lateral expansion of the dentary at the level of the fifth alveolus is followed by a posterior concavity, which ends at the level of the eleventh and twelfth alveoli (Figure 3a). The internal surface of the dentary is reduced from the region of the thirteenth and fourteenth alveoli, with a lateromedial thin splenial close to the medial margin of those and posterior alveoli (Figure 4a). Insofar, the posterior region of the lateral margin of the twelfth alveolus is not equivalent with the external limit of the dentary. The dentary region is convexly projected, being thicker than the medial part (Figure 3a). The dorsal surface of the dentary, near the medial margin of the alveoli, presents a continuous line of small, rounded, deep and well-delimited foramina, known as dental foramina that suggests neural and/or blood systems passage (Figure 3a). The ventral surface of the dentary also presents well-delimited rounded pits, those being mainly concentrated in the anterior part, and becoming sparse and spaced posteriorly until the disappearance after the level of the thirteenth alveolus (Figure 3b, 4a, c, d).

The splenial has the anterior half preserved in the medial surface of the left hemimandible, while the right hemimandible is mostly complete, missing only some portions of the posterior region (Figure $4 b$ ). Due to the fragmentary state of the splenial at the posterior region of the right hemimandible, we could not recognize the contacts with the coronoid (Figure 4b). In this fossil, the anteroventral surface of the foramen intermandibularis caudalis seems to be preserved (Figure 3b, 4b). The anterior end of the splenial, from both hemimandibles, does not reach the mandibular symphysis and it is bisected by the Meckelian groove (Figure 3c, 4b).

Only the anterior process of the surangular is preserved (Figure 3a, b). In lateral view, this process surpasses the anterior margin of the mandibular fenestra, reaching the level of the posterior margin of the twentysecond mandibular alveoli (Figure 3b). Despite unpreserved, the surangular does not exhibit contact to the anterior half of the mandibular fenestra (Figure 3b). In dorsal view, this process borders the lateral margin of the alveoli, reaching the posterior margin of the twentieth pair of alveoli (Figure 3a). This dorsal anterior process is bifid as consequence of a posterior process of dentary that contacts itmedially (Figure 1d,3a).

The angular surpasses the anterior margin of the mandibular fenestra, but prior to the end of the surangular lateral anterior process, this bone becomes restricted to the ventral margin of the mandible, reaching the level of the nineteenth alveoli (Figure 3b). The angular does not compose the anterior half of the mandibular fenestra (Figure 3b).

The presence and morphology of the coronoid cannot be provided, due to the fragmentary medial surface of the right hemimandible (Figure 4b).

Only the anterior half of the mandibular fenestra is preserved in the right hemimandible (Figure 3b). The posterior portion of the dentary exclusively composes this structure (Figure $3 b)$. The overall shape of the anterior portion indicates a long and tall mandibular fenestra, being slightly inclined dorsoventrally (Figure 3b).

The foramen intermandibularis caudalis has the anteroventral margin preserved in the medial surface of the right hemimandible (Figure 4b). No further information can be given due the fragmentary state of this portion. 
Some in situ teeth are partially preserved in the specimen DGM 527-R (Figure 1d, 3, 4). The right hemimandible has the second and fourth alveoli with preserved teeth; the second is fully erupted and exhibits a broken apical portion of the crown (Figure 5b); the fourth has only the tooth apex exposed, with the missing enamel (Figure 3a, 5b). In the left hemimandible, the second, third and fifth alveoli are preserved in situ (Figure 3a, 5b), being the second (Figure 5a) and the fifth fully erupted with the crown apex broken. The third has only the apex exposed with the enamel preserved. Those teeth are subcircular in cross-section with smooth enamel presenting longitudinal and transverse striae along the crown, while the anterior and posterior carinae are relatively coarse with crenulations forming perpendicular denticles (Figure 5c).

\section{DISCUSSION}

\section{Comparison}

The three specimens (the holotype, DGM 527$\mathrm{R}$ and UFAC 1118) present the first four dentary alveoli proportionally larger than in Purussaurus mirandai. Furthermore, UFAC 1118 has the $13^{\text {th }}$ alveolus larger than the posterior one to the fourth alveolus. Therefore, those specimens are recognized as $P$. brasiliensis.

The species Purussaurus brasiliensis is mainly known for three mandibular elements, which are: the holotype (Figure 1a-c), the specimen DGM 527-R (informally known as the neotype; Figure 1d, 3, 4), and the UFAC 1118 (associated with the most complete skull, UFAC 1403, of P. brasiliensis; Bocquentin-Villanueva et al. 1989, Aureliano et al. 2015). The preserved portions of the holotype and the specimen UFAC 1118 share the same descriptions as here proposed for DGM 527-R. The specimen UFAC 1118 differs by not presenting the splenial suture visible, and the Meckelian fossa and canals enclosed, whereas the holotype is neither fully prepared nor described, which enable a proper verification of this feature. Another difference is the total number of alveoli in dentary, which is 21 for DGM 527-R; 20 for UFAC 1118 and unknown for the holotype. Those differences related to UFAC 1118 could be both related to the preservation type of the specimen, which presents the external surface modified by the fossilization process, or due to ontogenetic differences.

All specimens attributed to Purussaurus (Table II) present the following features: 1) false ziphodont teeth (as proposed by Aguilera et al. 2006, Aureliano et al. 2015, Souza et al. 2016); 2) two well-marked dorsal concavities in the lateral view of the mandible, one between the first and fourth alveoli and the other between the fourth to eleventh alveoli, with the dorsal margin inclined dorsally from the region behind the eleventh alveolus; 3 ) in dorsal view of the lateral margin between the fourth and twelfth alveoli presenting a well-marked dorsal concavity in the lateral view of the mandible; 4) thin medial surface of the mandible from the fourteenth alveolus towards the posterior, while the lateral surface becomes laterally expanded from the ninth alveoli to the posterior ones; 5) the mandibular symphysis extending to the mid portion of the fifth alveolus; and 6) the anterior margin of the mandible markedly convex due to the anterior position of the second alveoli and the lateral position of the third and fourth alveoli. The main differences between the specimens of the Purussaurus species are related to the number of dentary alveoli, with DGM 527-R ( $P$. brasiliensis) presenting 21, similar to $P$. mirandai and differing from the most complete mandible of $P$. neivensis (MUSM 1392) that has 19-20 and UFAC 1118 (P. brasiliensis) which has 20.

The specimens of Purussaurus can be considered as presenting some heterodonty in 
their dentition as observed in other crocodylians (D'Ampore et al. 2019) with tall, slight compressed labio-lingually and sharp teeth in the anterior alveoli, while the posterior ones are rounded and blunted (Langston 1965, Aguilera et al. 2006, Aureliano et al. 2015, Souza et al. 2016). The false ziphodont condition (sensu Prasad \& de Broin 2002) is proposed for Purussaurus teeth (Aguilera et al. 2008, Aureliano et al. 2015, Souza et al. 2016). This condition seems to be, at least among eusuchians, exclusive to this genus, being observed in the remaining eusuchian species the conidont (sensu Hendrickx et al. 2015, also, see D'Amore et al. 2019) or ziphodont tooth morphologies (Mekosuchinae and Planocraniidae; e.g., Brochu 2013). Within Alligatoroidea and more specifically Caimaninae, all specimens present the conidont, and can present a degree of heterodonty, regarding the morphology of anterior and posterior teeth (D'Amore et al. 2019).

The specimens of Purussaurus present two well-marked dorsal concavities in the lateral view of the mandible, being the first one between the first and fourth alveoli, and the second one between the fourth to eleventh alveoli. In the former, the dorsal margin is dorsally inclined from the region behind the eleventh alveoli. This condition is similar to the one observed in the specimens of Acresuchus pachytemporalis, Bottosaurus harlani, Caiman latirostris, Krabisuchus siamogallicus, Melanosuchus niger and Necrosuchus ionensis. The specimens of Mourasuchus present this surface straight, while the remaining specimens of Caimaninae have a well-marked convexity at the level of the ninth to thirteenth alveoli, posteriorly followed by a concavity. These Caimaninae include C. crocodilus, C. yacare, C. brevirostris, Ceratosuchus burdoshi; Eocaiman cavernensis, E. paleocenicus, E. itaboraiensis, Gnatusuchus pebasensis, Globidentosuchus brachyrostris,
Kuttanacaiman iquitosensis, Navajosuchus mooki, Paleosuchus, Procaimanoidea utahensis, Procaimanoidea kayi and Wannaganosuchus brachymanus.

In the lateral margin of the mandible between the fourth to the twelfth alveoli, there is a well-marked dorsal concavity in the lateral view of the mandible in Purussaurus specimens and Acresuchus pachytemporalis, Caiman crocodilus, C. latirostris, C. yacare, Melanosuchus niger, Gnatusuchus pebasensis, Necrosuchus ionensis, and Notocaiman stromeri. This feature contrasts with the straight morphology observed among specimens of Bottosaurus harlani, C. brevirostris, Ceratosuchus burdoshi, Eocaiman cavernensis, E. paleocenicus, E. itaboraiensis, Globidentosuchus brachyrostris, Krabisuchus siamogallicus; Mourasuchus, Navajosuchus mooki, Paleosuchus, Procaimanoidea kayi, Tsoabichi greenriverensis, and Wannaganosuchus brachymanus. This straight morphology was also observed in extant specimens at early ontogenetic phases such as C. crocodilus (MZUSP-C 2113; MZUSP-C 2014; MZUSP-C 2063; AMNH R 73048; AMNH R 137179), C. latirostris (AMNH R 143183), C. yacare (AMNH R 97334) and M. niger (AMNH R 101419).

A condition only observed among the studied specimens of Purussaurus was the relative thinning of the medial surface of the mandible posterior to the fourteenth alveoli pair, while the lateral surface becomes laterally expanded, starting at the ninth alveoli pair, and extending posteriorly. Those medial and lateral variations are here initially considered as biologically dependent (see Fitzhugh 2006) and, more specifically, dependent of the position of the toothline relative to the mandible long axis (i.e. closer to the medial surface than to the lateral one in dorsal view). Therefore, are treated together aiming for a unique explanation for this whole condition. The remaining specimens, Acresuchus 
pachytemporalis, Bottosaurus harlani, Caiman brevirostris, C. crocodilus, C. latirostris, C. yacare, Ceratosuchus burdoshi, Eocaiman cavernensis, E. paleocenicus, E. itaboraiensis, Gnatusuchus pebasensis, Globidentosuchus brachyrostris, Krabisuchus siamogallicus, Melanosuchus niger, Mourasuchus, Navajosuchus mooki, Necrosuchus ionensis, Notocaiman stromeri, Paleosuchus, Procaimanoidea kayi, Tsoabichi greenriverensis and Wannaganosuchus brachymanus, present variations between thinner and longer hemimandibles that do not fit with the morphological condition here described for Purussaurus.

All specimens assigned to Purussaurus have the mandibular symphysis extending posteriorly, precisely, to the level of the mid portion of the fifth alveolus. There are several contrasting conditions, such as the symphysis extending by one alveolus, which correspond to the first alveolus, in Mourasuchus specimens, to the other which extends between fourth and fifth alveoli (Acresuchus pachytemporalis, Necrosuchus ionensis, Paleosuchus, Procaimanoidea utahensis and Tsoabichi greenriverensis), fifth to sixth (Caiman crocodilus, Caiman latirostris, Caiman yacare, Caiman brevirostris, Ceratosuchus burdoshi, Eocaiman cavernensis, Eocaiman paleocenicus, Eocaiman itaboraiensis, Globidentosuchus brachyrostris, Melanosuchus niger, Procaimanoidea kayi and Wannaganosuchus brachymanus) or seventh to more (Gnatusuchus pebasensis, Navajosuchus mooki and Notocaiman stromeri).

Some caimanine specimens present the anterior margin of the mandible markedly convex, being a consequence of the anterior positioning of the second alveoli, displaced laterally to the posterior margin of the first alveoli, and the more lateral positioning of the third and fourth alveoli to the second. This condition was observed among Purussaurus and in the specimens of Ceratosuchus burdoshi, Eocaiman cavernensis, Eocaiman paleocenicus, Eocaiman itaboraiensis, Gnatusuchus pebasensis, Mourasuchus, Navajosuchus mooki, Notocaiman stromeri and Wannaganosuchus brachymanus. The contrasting condition is the one with a more pointed anterior margin, as the result of the second alveolus being displaced posterolaterally relative to the first, the third and the fourth are aligned with the second. This condition matches with specimens of Acresuchus pachytemporalis, Caiman crocodilus, Caiman latirostris, Caiman yacare, Melanosuchus niger, Caiman brevirostris, Necrosuchus ionensis; Paleosuchus, Procaimanoidea utahensis and Tsoabichi greenriverensis.

\section{MANDIBULAR CHARACTERS OF PURUSSAURUS: POTENTIAL SYNAPOMORPHIES AND AUTAPOMORPHIES}

As only Purussaurus brasiliensis specimens are considered in this work and as the specimens attributed to the remaining Purussaurus species miss all views figured and some mandibular features are not described, the content here proposed must be verified and reviewed by future works, in which authors could personally study the remaining specimens. Therefore, these commentaries are an important guideline for future contributions to the understanding of Purussaurus paleobiology and evolution.

In a preliminary work, G. M. Cidade \& A. Hsiou (unpublished data) revisited the types of Purussaurus species aiming to review their diagnoses. They concluded that the size variations in the first four mandibular alveoli are enough to distinguish such specimens in different species. The present contribution considers this differentiation method with 
caution due to such size variations that are directly related to the specimen's size. Tounderstand their phylogenetic signal and potential taxonomic value, the allometric and the ontogenetic development of such features should be at first understood (further discussion of feature variation among crocodylian species in Brochu \& Sumrall, 2020). Therefore, we do not consider such results as applicable, for now, waiting for the conclusion of their work.

From the six mandibular features discussed here, some interesting implications could be inferred. There are at least two potential synapomorphies for Purussaurus that must have their homologues (sensu Owen, 1847; Fitzhugh 2006) tested and latter included in future phylogenetic inferences (sensu Souza 2017). These characters are the false ziphodont teeth and the thinning of the medial surface of the mandible posterior to the fourteenth alveoli, while the lateral surface becomes laterally expanded from the ninth alveoli and extending posteriorly. The features related to the mandibular symphysis reaching the mid portion of the fifth alveoli could be potentially considered as an interesting condition; however, variations in the mandibular symphysis length are quite common among crocodylians and should be treated with caution. The other three characters, two related to the dorsal concavities in the lateral view of the mandible and the latter with the anterior mandibular margin morphology, are features directed related with alimentary habits and their homologues must be tested prior to the inclusion in new phylogenetic inferences aiming to verify if those similarities reflect convergent feeding habits (becoming analogues) or related to ontogenetic development.

This contribution does not find any new autapomorphic mandibular feature for the Purussaurus species. In the literature, only
P. neivensis presents an autapomorphic mandibular feature that was described by Langston (1965), which is the development of a well-marked ridge in the lateral surface of the angular. It is important to note that the absence of mandibular autapomorphies is not definitive, as this we could not handle first-hand the specimens of $P$. neivensis nor P. mirandai, being strongly limited and biased by poor preservation of many specimens and, often, poor description of the data. The review of such species, considering what was here discussed, is strongly recommended for future works.

\section{CONCLUSIONS}

The extensive field works made by L. I. Price and D. A. Campos in the Solimões Formation enabled the finding of important materials, including the specimen informally regarded as the neotype of Purussaurus brasiliensis. The curatorial efforts initiated by Price and kept by Campos made possible the revision of DGM 527- $R$, an important specimen for the understanding of the paleobiology and evolution of $P$. brasiliensis and the genus as a whole. Such importance was recognized here scientifically by Campos when he considered this specimen as the centerpiece of the exhibition in honor of the one hundred anniversary of Price.

Regarding the scientific novelty here produced, we have identified six new mandibular characters that should be considered in future contributions about caimanine evolution. Also, from such characters, at least two indicate synapomorphies for Purussaurus. The only species of the genus that have had a mandibular autapomorphy recognized here is Purussaurus neivensis, which further anatomical and homologue studies should properly address the autapomorphies of such 
key species to the genus. The reduced resources for the development of this project hampers us from analyzing first-hand the non-Brazilian specimens, and the culture of not completely illustrating and describing the mandibular materials created a strong bias and limitation to this work. Therefore, as made here, future studies should provide better illustrations and descriptions of described materials to enable scientific progress.

\section{Acknowledgments}

We thank curator Rafael Costa (MCT/DNPM) for allowing access to the specimen described here and for his help during its examination. In addition, our acknowledgments to Diogenes de Almeida Campos, honored in this special volume, due to his valuable contributions about the specimen studied here, as well as his fieldwork notes. We also thank the editors for inviting us to participate in this special volume. We posthumously thank the academic and personal efforts made by L.W. Price, who greatly improved (and still promotes nowadays) Brazilian paleontology. Christopher Brochu, Aline Ghilardi and Torsten Scheyer are thanked for comments and useful suggestions on the manuscript. Thanks to Victoria Barros for the English review. The paper was improved by photos of non-Brazilian Purussaurus specimens provided by Douglas Riff (UFU) and Giovanne Cidade (UFSCAR). LGS thanks the paleo and geohistory exhibition at Museu da Amazônia (PRONAC 183808) the post-doctoral scholarship granted by Fundação de Amparo à Pesquisa do Estado do Amazonas (FAPEAM 062.00166/2020). RVP thanks FAPESP for a scholarship (\#2019/10231-6). ASB is grateful for his Doctorate scholarship from Coordenação de Aperfeiçoamento de Pessoal de Nivel Superior (CAPES -PROANTAR fellowship \# 88887.336584/2019-00).

\section{REFERENCES}

AGUILERA, OA, RIFF, D, \& BOCQUENTIN-VILLANUEVA J. 2006. A new giant Purussaurus (crocodyliformes, alligatoridae) from the upper Miocene Urumaco formation, Venezuela. J Syst Palaeontol 4(3): 221-232

AURELIANO T, GHILARDI AM, GUILHERME E, SOUZA-FILHO JP, CAVALCANTI M \& RIFF D. 2015. Morphometry, bite-force, and paleobiology of the Late Miocene Caiman Purussaurus brasiliensis. PloS One 10(2): e0124188.
BARBOSA-RODRIGUES J. 1892. Les Reptiles fossiles de la vallée de l'Amazone. Vellosia 2: 41-46.

BARTELS WS. 1984. Osteology and systematic affinities of the horned alligator Ceratosuchus (Reptilia, Crocodylia). J Paleontol 58(6): 1347-1353.

BISSARO-JÚNIOR MC, KERBER L, CROWLEY JL, RIBEIRO AM, GHILARDI RP, GUILHERME E, NEGRI FR, SOUZA-FILHO JP \& HSIOU AS. 2018. Detrital zircon $\mathrm{U}-\mathrm{Pb}$ geochronology constrains the age of Brazilian Neogene deposits from Western Amazonia. Palaeogeogr Palaeoclimatol Palaeoecol 516: 64-70.

BLANCO RE, JONES WW \& VILLAMIL J. 2015. The 'death roll' of giant fossil crocodyliforms (Crocodylomorpha: Neosuchia): allometric and skull strength analysis. Hist Biol 27(5): 514-524.

BOCQUENTIN-VILLANUEVA J, SOUZA-FILHO JP, BUFFETAUT E \& NEGRI FR. 1989. Nova interpretação do gênero Purussaurus (Crocodylia, Alligatoridae). In: SBP, editor. Anais do XI Congresso Brasileiro de Paleontologia. Curitiba: Sociedade Brasileira de Paleontologia, p. 427-438.

BONA P. 2007. Una nueva especie de Eocaiman Simpson (Crocodylia, Alligatoridae) del Paleoceno Inferior de Patagonia. Ameghiniana 44(2): 435-445.

BONA P \& BARRIOS F. 2015. The Alligatoroidea of Argentina: an update of its fossil record. Publicación Electrónica de la Asociación Paleontológica Argentina 15(1).

BOND M, TEJEDOR MF, CAMPBELL FR KE, CHORNOGUBSKY L, NOVO N \& GOIN F. 2015. Eocene primates of South America and the African origins of New World monkeys. Nature 520: 538-541.

BRAZIL. 1976. Departamento Nacional da produção mineral. Projeto RADAMBRASIL, Folha SC. 19 Rio Branco: geologia, geomorfologia, pedologia, vegetação e uso potencial da terra. Rio de Janeiro, $443 \mathrm{p}$.

BROCHU CA. 2010. A new alligatorid from the lower Eocene Green River Formation of Wyoming and the origin of caimans. J Vertebr Paleontol 30(4): 1109-1126.

BROCHU CA. 2011. Phylogenetic relationships of Necrosuchus ionensis Simpson, 1937 and the early history of caimanines. Zool J Linn Soc 163(suppl. 1): S228-S256.

BROCHU CA. 2013. Phylogenetic relationships of Palaeogene ziphodont eusuchians and the status of Pristichampsus Gervais, 1853. Earth Environ Sci Trans R Soc Edinb 103(3-4): 521-550.

BROCHU CA \& SUMRALL CD. 2020. Modern cryptic species and crocodylian diversity in the fossil record. Zool J Linn Soc: zlaa039. 
CAPUTO M, RODRIGUES V \& VASCONCELOS D. 1971. Litoestratigrafia da bacia do rio Amazonas. Litoestratigrafia da Bacia do Rio Amazonas. Relatorio Técnico interno, Petrobras-renor, 641 p.

CIDADE GM, FORTIER D \& HSIOU AS. 2019C. Taxonomic and phylogenetic review of Necrosuchus ionensis (Alligatoroidea: Caimaninae) and the early evolution and radiation of caimanines. Zool J Linn Soc: zlz051.

CIDADE GM, SOLÓRZANO A, RINCÓN AD, RIFF D \& HSIOU AS. 2017. A new Mourasuchus (Alligatoroidea, Caimaninae) from the late Miocene of Venezuela, the phylogeny of Caimaninae and considerations on the feeding habits of Mourasuchus. Peerj 5: e3056.

CIDADE GM, RIFF D, DE SOUZA-FILHO JP \& HSIOU AS. 2019a. A reassessment of the osteology of Mourasuchus amazonensis Price, 1964 with comments on the taxonomy of the species. Palaeontologia Electronica 22(2): $44 \mathrm{a}$.

CIDADE GM, SOUZA-FILHO JP, HSIOU AS, BROCHU CA, \& RIFF D. 2019b. New specimens of Mourasuchus (Alligatoroidea, Caimaninae) from the Miocene of Brazil and Bolivia and their taxonomic and morphological implications. Alcheringa: An Australasian Journal of Palaeontology 43(2): 261-278.

COSSETTE AP \& BROCHU CA. 2018. A new specimen of the alligatoroid Bottosaurus harlani and the early history of character evolution in alligatorids. J Vertebr Paleontol 38(4): 1-22.

CUNHA PRC. 2007. Bacia Acre. Boletim Geociências Petrobras. Boletim Geociências Petrobrás 15(2): 207-2015.

D'AMORE DC, HARMON M, DRUMHELLER SK \& TESTIN JJ. 2019. Quantitative heterodonty in Crocodylia: assessing size and shape across modern and extinct taxa. Peerf 7 : e6485.

ERICKSON BR. 1982. Wannaganosuchus, a new alligator from the Paleocene of North America. J Paleontol 56(2): 492-506.

FITZHUGH K. 2006. The philosophical basis of character coding for the inference of phylogenetic hypotheses. Zool Scr 35: 261-286.

FORTIER DC, DE SOUZA-FILHO JP, GUILHERME E, MACIENTE AA \& SCHULTZ CL. 2014. A new specimen of Caiman brevirostris (Crocodylia, Alligatoridae) from the Late Miocene of Brazil. J Vertebr Paleontol 34(4): 820-834.

GERVAIS P. 1876. Crocodile gigantesque fossile au Bresil. Can J Zool 5: 232-236.

GILMORE CW. 1946. A new crocodylian from the Eocene of Utah. J Paleontol 20(1): 62-67.
HASTINGS AK, BLOCH JI, JARAMILLO CA, RINCON AF \& MACFADDEN BJ. 2013. Systematics and biogeography of crocodylians from the Miocene of Panama. J Vertebr Paleontol 33(2): 239-263.

HENDRICKX C, MATEUS O \& ARAÚJO R. 2015. A proposed terminology of theropod teeth (Dinosauria, Saurischia). J Vertebr Paleontol 35: 1-18.

IORDANSKY NN. 1973. The skull of the Crocodylia. In: Gans C \& Parsons T (Eds), Biology of the Reptilia, London: Academic press, 4: 201-260.

LANGSTON W. 1965. Fossil Crocodylians from Colombia and the Cenozoic history of the Crocodylia in South America, Berkeley: University of California Press, $167 \mathrm{p}$.

LATRUBESSE EM, COZZUOL M, SILVA-CAMINHA SAF, RIGSBY CA, ABSY ML \& JARAMILLO C. 2010. The Late Miocene paleogeography of the Amazon Basin and the evolution of the Amazon River system. Earth Sci Rev 99: 99-124.

LATRUBESSE E \& RANCY A. 2000. Neotectonic influence on tropical rivers of southwestern Amazon during the late Quaternary: the Moa and Ipixuna river basins, Brazil. Quat Int 72: 67-72.

LUCAS SG \& ESTEP JW. 2000. Osteology of Allognathosuchus mooki Simpson, a Paleocene crocodylian from the San Juan Basin, New Mexico, and the monophyly of Allognathosuchus. Bull N M Mus Nat Hist Sci 16: 155-168.

MARTIN JE \& LAUPRASERT K. 2010. A new primitive alligatorine from the Eocene of Thailand: relevance of Asiatic members to the radiation of the group. Zool J Linn Soc 158(3): 608-628.

MOOK CC. 1921a. Brachygnathosuchus brasiliensis, a new fossil crocodylian from Brazil. Bull Am Mus Nat Hist 44: 43-49.

MOOK CC. 1921b. Skull characters of Recent Crocodylia, with notes on the amnietes of the Recent genera. Bull Am Mus Nat Hist 44 (13): 123-268.

MOOK CC. 1941a. A new fossil Crocodylian from Colombia. Proc U S Natl Mus 91(3122): 55-58.

MOOK CC. 1941b. A new crocodylian, Hassiacosuchus kayi, from the Bridger Eocene beds of Wyoming. Ann Carnegie Mus 28: 207-220.

MOOK CC, GRANGER W, SINCLAIR WJ \& OLSEN G. 1942. A new fossil crocodylian from the Paleocene of New Mexico. Am Mus Novit 1189: 1-4.

OWEN R. 1847. Report on the archetype and homologies of the vertebrate skeleton. Report on the Meeting of the British Association for the Advancement of Science 16: 169-340. 
PATTERSON B. 1936. Caiman latirostris from the Pleistocene of Argentine, and a Summary of South American Cenozoic Crocodylia. Herpetologica 1: 43-54.

PATTERSON B. 1943. Remarks on South American Crocodiles. Copeia 1943: 123-124.

PINHEIRO AE, FORTIER DC, POL D, CAMPOS DA \& BERGQVIST LP. 2013. A new Eocaiman (Alligatoridae, Crocodylia) from the Itaboraí Basin, Paleogene of Rio de Janeiro, Brazil. Hist Biol 25(3): 327-337.

PRASAD GVR \& DE BROIN FL. 2002. Late Cretaceous crocodile remains from Naskal (India): comparisons and biogeographic affinities Ann Paleontol 88: 19-71.

PRICE LI. 1967. Sobre a mandíbula de um gigantesco crocodilídeo extinto do alto Rio Juruá, Estado do Acre. In: Lent H (Ed), Atas Simpósio sobre a Biota Amazônica (Geociências). Belém: Sociedade Brasileira de Paleontologia 1: 359-371.

PRICE LI, CAMPOS DA \& CAMPOS DRB. 1977. Localidades fossilíferas das Folhas SB.18 Javari e SC.18 Contamana. In: Barros AM, Alvezedo, Araujo JFV, Lima MIC \& Fernandes CAC (Eds), Geologia, Rio de Janeiro, Projeto RadamBrasil. Levantamento de Recursos Naturais 13: 17-103.

RIFF D, ROMANO PSR, OLIVEIRA GR \& AGUILERA OA. 2010. Neogene crocodile and turtle fauna in northern South America. In: Hoorn C \& Wesselingh FP (Eds), Amazonia: Landscape and Species Evolution: A Look into the Past. Oxford: Wiley-Blackwell, p. 259-280.

ROMER AS. 1956. Osteology of the Reptiles. Chicago: University of Chicago Press, $3^{\text {rd }}$ ed., 772 p.

SALAS-GISMONDI R, FLYNN JJ, BABY P, TEJADA-LARA JV, WESSELINGH FP \& ANTOINE PO. 2015. A Miocene hyperdiverse crocodylian community reveals peculiar trophic dynamics in proto-Amazonian mega-wetlands. Proc R Soc B: Biological Sciences 282(1804): 20142490.

SCHEYER TM, AGUILERA OA, DELFINO M, FORTIER DC, CARLINI AA, SÁNCHEZ R \& SÁNCHEZ-VILLAGRA MR. 2013. Crocodylian diversity peak and extinction in the late Cenozoic of the northern Neotropics. Nat Comm 4(1): 1-9.

SCHEYER TM \& DELFINO M. 2016. The late Miocene caimanine fauna (Crocodylia: alligatoroidea) of the Urumaco Formation, Venezuela. Palaeontol Electronica 19(3): 1-57.

SCHEYER TM, HUTCHINSON JR, STRAUSS O, DELFINO M, CARRILLOBRICEÑO JD, SÁNCHEZ R \& SÁNCHEZ-VILLAGRA MR. 2019. Giant extinct caiman breaks constraint on the axial skeleton of extant crocodylians. eLife 8: 449972.
SIMPSON GG. 1930. Allognathosuchus mooki, a new crocodile from the Puerco Formation. Am Mus Novit 445: $1-16$.

SIMPSON GG. 1933. A new crocodylian from the Notostylops beds of Patagonia. Am Mus Novit 623: 1-9.

SIMPSON GG. 1937. An ancient eusuchian crocodile from Patagonia. Am Mus Novit 956: 1-20.

SOLÓRZANO A, RINCÓN AD, CIDADE GM, NÚÑEZ-FLORES M \& SÁNCHEZ L. 2018. Lower Miocene alligatoroids (Crocodylia) from the Castillo Formation, northwest of Venezuela. Paleobiodivers Paleoenviron 99(2): 241-259.

SouZA RG. 2017. Críticas ao 'Tree Thinking': elucidando o significado das relações filogenéticas. Pesquisa e Ensino em Ciências Exatas e da Natureza 1(2): 115-130.

SOUZA RG. 2018. Comments on the Serial Homology and Homologues of Vertebral Lateral Projections in Crocodylia (Eusuchia). Anat Rec 301(7): 1203-1215.

SOUZA RG, CIDADE GM, CAMPOS DA \& RIFF D. 2016. New crocodylian remains from the Solimões Formation (Lower Eocene-Pliocene), State of Acre, Southwestern Brazilian Amazonia. Rev Bras Paleontol 19(2): 217-232.

SOUZA-FILHO JP. 1987. Caiman brevirostris sp. nov., um novo Alligatoridae da Formação Solimões (Pleistoceno) do Estado do Acre, Brasil. In: X Congresso Brasileiro de Paleontologia, Rio de Janeiro, p. 173-180.

SOUZA-FILHO JP, SOUZA RG, HSIOU AS, RIFF D, GUILHERME E, NEGRI FR \& CIDADE GM. 2019. A new caimanine (Crocodylia, Alligatoroidea) species from the Solimões Formation of Brazil and the phylogeny of Caimaninae. J Vertebr Paleontol 38(5): e1528450.

\section{How to cite}

SOUZA LG, BANDEIRA KLN, PÊGAS RV, BRUM AS, MACHADO R, GUILHERME E, LOBODA TS \& SOUZA-FILHO JP. 2021. The history, importance and anatomy of the specimen that validated the giant Purussaurus brasiliensis Barbosa-Rodrigues 1892 (Crocodylia: Caimaninae). An Acad Bras Cienc 93: e20200369. DOI 10.1590/0001-3765202120200369.

Manuscript received on March 20, 2020;

accepted for publication on September 6, 2020

\section{LUCY G. DE SOUZA 1}

https://orcid.org/0000-0003-2819-7776

\section{KAMILA L.N. BANDEIRA ${ }^{2}$}

https://orcid.org/0000-0002-2744-8126

\section{RODRIGO V. PÊGAS}

https://orcid.org/0000-0003-2909-3346 
ARTHUR S. BRUM ${ }^{2}$

https://orcid.org/0000-0003-3927-0318

RODRIGO MACHADO 4

https://orcid.org/0000-0001-9057-0055

EDSON GUILHERME

https://orcid.org/0000-0001-8322-1770

THIAGO S. LOBODA

https://orcid.org/0000-0003-4212-7889

JONAS P. DE SOUZA-FILHO 5

https://orcid.org/0000-0003-0481-3204

1'Museu da Amazônia (MUSA), Avenida Margarita, 6305, Jorge Teixeira, 10795-265 Manaus, AM, Brazil

${ }^{2}$ Universidade Federal do Rio de Janeiro, Laboratório de Sistemática e Tafonomia de Vertebrados Fósseis, Departamento de Geologia e Paleontologia, Museu Nacional, Quinta da Boa Vista, s/n, São Cristóvão, 20940-040 Rio de Janeiro, RJ, Brazil

${ }^{3}$ Universidade Federal do ABC, Laboratório de Paleontologia de Vertebrados e Comportamento Animal, Alameda da Universidade, s/n, Anchieta, 09606-045 São Bernardo do Campo, SP, Brazil ${ }^{4}$ CPRM, Museu de Ciências da Terra, Av. Pasteur, 404, Urca, 22290-240 Rio de Janeiro, RJ, Brazil ${ }^{5}$ Universidade Federal do Acre, Laboratório de Pesquisas Paleontológicas, Rodovia BR 364, Km 04, Distrito Industrial, 69915-900 Rio Branco, AC, Brazil

Correspondence to: Lucy Gomes de Souza

E-mail:souzalucyg@gmail.com

\section{Author contributions}

Lucy Gomes de Souza: conceptualization, writing, material and methods, figures and revision. Kamila Luisa Nogueira Bandeira: writing, material and methods, figures and revision. Rodrigo Vargas Pêgas: writing, material and methods, figures and revision. Arthur Souza Brum: writing, material and methods, figures and revision. Rodrigo Machado: material and methods and revision. Edson Guilherme: material and methods and revision. Thiago Silva Loboda: material and methods and revision. Jonas Pereira de Souza-Filho: conceptualization and revision.

\section{(cc) $\mathrm{BY}$}

